\title{
COMPARISONS AND INTERPRETATIONS OF CHARCOAL AND ORGANIC MATTER RADIOCARBON AGES FROM BURIED SOILS IN NORTH-CENTRAL COLORADO, USA
}

\begin{abstract}
James H Mayer ${ }^{1}$ George S Burr ${ }^{2}$ Vance T Holliday ${ }^{3}$
ABSTRACT. The reliability of radiocarbon ages based on soil organic matter (SOM) from Holocene buried soils in Middle Park, Colorado, is assessed by comparison with ages of charcoal. On average, ${ }^{14} \mathrm{C}$ ages of SOM from buried surface horizons are $880 \pm 230{ }^{14} \mathrm{C}$ yr younger than charcoal ages from the same horizon. Humic acid (HA) and low-temperature $\left(400{ }^{\circ} \mathrm{C}\right)$ combustion residue (LT) fractions are $390 \pm 230$ and $1290 \pm 230{ }^{14} \mathrm{C}$ yr younger than charcoal ages, respectively, and HA ages are on average $860 \pm 140{ }^{14} \mathrm{C}$ yr older than LT fractions. We interpret the offsets between ${ }^{14} \mathrm{C}$ ages of charcoal and SOM fractions and the consistent offsets between the HA and LT fractions to reflect the duration of pedogenesis and different residence times of the SOM fractions examined here. The stratigraphic coherence of charcoal ${ }^{14} \mathrm{C}$ ages suggests short residence time on the landscape, with little subsequent reworking. ${ }^{14} \mathrm{C}$ ages of HA and LT fractions are complimentary to charcoal, and HA ages are interpreted to represent minimum ages for the onset of pedogenesis and LT ages are considered maximum ages for burial. The ${ }^{14} \mathrm{C}$ chronology from buried soils indicates an episode of hillslope erosion in Middle Park during the early Holocene, followed by a long period of land surface stability and soil formation between 9000-4500 BP. Two episodes of late Holocene hillslope erosion between 3500-2500 and 1000-500 BP correspond with warming recognized in the Colorado Front Range, while surface stability and soil formation between 2500-1000 BP is contemporaneous with evidence for cooling at higher elevations.
\end{abstract}

\section{INTRODUCTION}

Buried soils preserve important information related to landscape evolution and environmental change, and have long played a central role in geomorphology, geoarchaeology, and Quaternary geology (Catt 1986; Daniels and Hammer 1992; Gerrard 1992; Birkeland 1999; Holliday 2004, 2006; Schaetzl and Anderson 2005; Goldberg and Macphail 2006). Determining the ages of buried soils in a stratigraphic section can provide a temporal framework for interpreting the relative land surface stability of a particular region through time. Pedogenesis is a function of several environmental factors (Jenny 1941), and soil morphological characteristics may be indicative of soil-forming environments (Holliday 1994, 2004; Birkeland 1999). Thus, such age control may also be used to understand the timing of environmental change. Because soils are surface phenomena, determining the age of a buried soil can be important in assessing the archaeological potential of buried landscapes (Holliday 2004).

Disagreement exists on the reliability of radiocarbon ages based on soil organic matter (SOM). In arid and semi-arid environments, where more traditional materials for dating such as wood, charcoal, peat, or other organic remains are largely absent from late Quaternary deposits, ${ }^{14} \mathrm{C}$ ages of SOM are routinely utilized for chronological control and produce reasonable results (e.g. Mandel 1992, 1995; Holliday et al. 1994; Quade et al. 1998, 2008; Johnson and Willey 2000; Daniels 2003; Rawling et al. 2003). In other cases, ${ }^{14} \mathrm{C}$ ages based on SOM have been viewed with skepticism (Geyh et al. 1983; Evans 1995; Trumbore 2000). It has been shown that in some cases SOM ${ }^{14} \mathrm{C}$ ages reflect a time-averaged integration of carbon from multiple sources in a soil system (Polach and Costin 1971; Gilet-Blein et al. 1980; Goh 1980; Geyh et al. 1983; Wang et al. 1996), variously referred to as the "time of residence" (Tamm and Östlund 1960), "mean residence time" (Campbell et al. 1967; Scharpenseel 1971), or "apparent mean residence time" (Scharpenseel and Schiffmann 1977; Matthews 1980, 1985). An additional uncertainty may exist when consistent age relationships

\footnotetext{
${ }^{1}$ Department of Geosciences, University of Arizona, Tucson, Arizona 85721, USA. Corresponding author. Email: jhmayer@email.arizona.edu.

${ }^{2}$ NSF-Arizona AMS Laboratory, University of Arizona, Tucson, Arizona 85721, USA.

${ }^{3}$ Departments of Anthropology and Geosciences, University of Arizona, Tucson, Arizona 85721, USA.
} 
between carbon from different soil humus fractions are lacking (e.g. Gilet-Blein et al. 1980; Haas et al. 1986; Martin and Johnson 1995; McGeehin et al. 2001; Wang et al. 2003), and, in some cases, buried soils may be susceptible to exchange with carbon in surface soils through rootlet penetration, bioturbation, and percolation of soluble organic substances (Geyh et al. 1983). Buried soils may also produce anomalously old ages if partially truncated prior to burial (Martin and Johnson 1995) or if SOM is inherited through erosion and redeposition of upland soils (Nordt 2004). Consideration of all of these factors must preface any interpretation of SOM ${ }^{14} \mathrm{C}$ results.

Here, we present ${ }^{14} \mathrm{C}$ ages from buried soils occurring in Middle Park, Colorado, an intermontane basin in the Southern Rocky Mountains, USA (Figure 1). Previous work in western Middle Park documented buried soils occurring in upland hillslope settings and adjacent valley fills in first-order drainages (Kornfeld et al. 1999; Mayer et al. 2005, 2007). A recurring soil-stratigraphic unit in uplands is a moderately developed buried soil informally referred to here as the Kremmling soil (Figure 2). Determining the age of the soil is important for understanding landscape evolution and Holocene environmental change, which have archaeological implications. Middle Park contains an abundance of Paleoindian archaeological components (Kornfeld and Frison 2000), some of which occur in buried soils (Kornfeld et al. 1999; Mayer et al. 2005, 2007; Surovell et al. 2005).

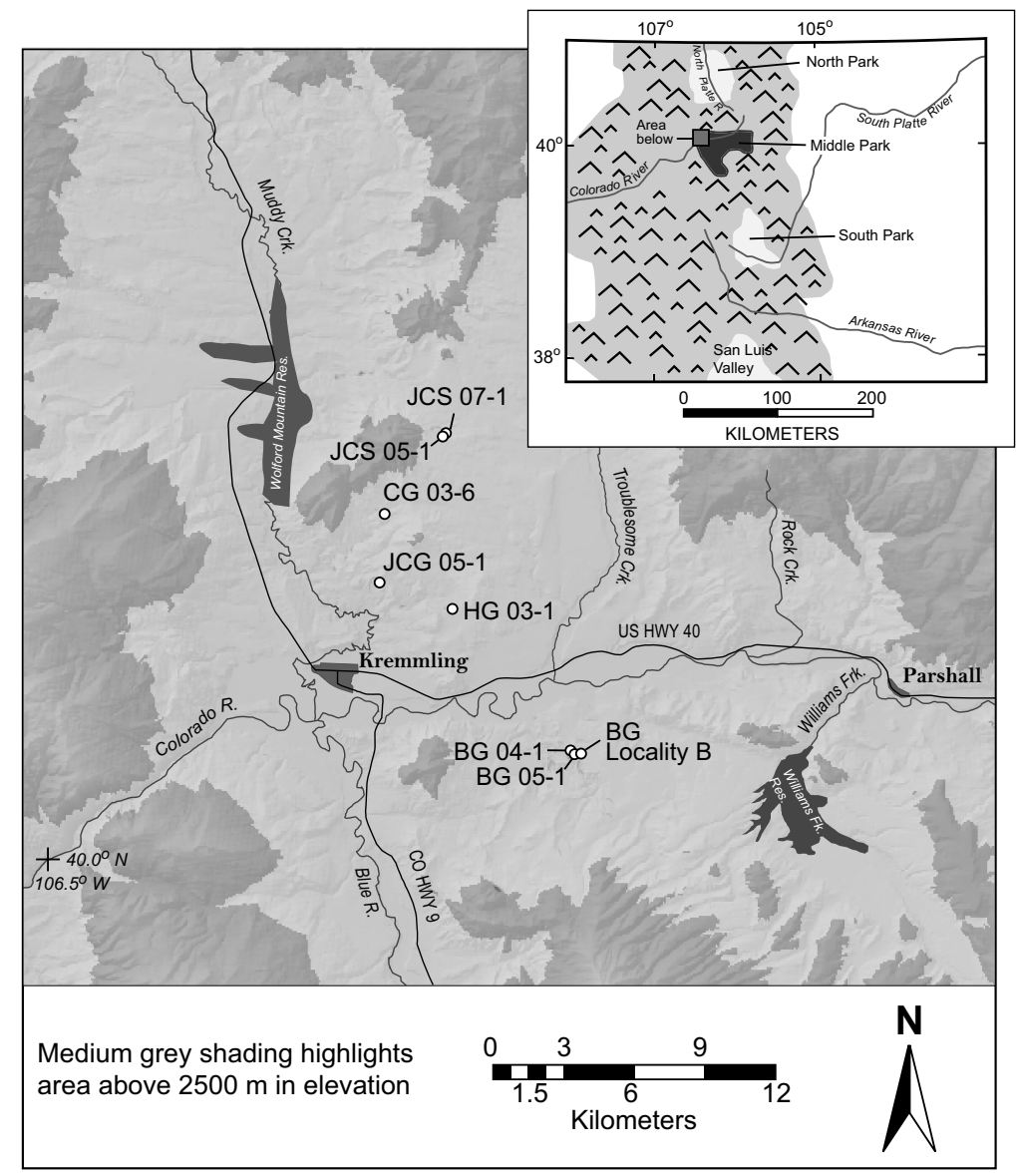

Figure 1 Sample localities in western Middle Park. Inset shows location of Middle Park in north-central Colorado BG = Barger Gulch, $\mathrm{CG}=$ Cow Gulch, $\mathrm{HG}=$ Horse Gulch, $\mathrm{JCG}=$ Jeep Crawl Gulch, JCS = Jerry Craig site. See Table 1 for summary of sample locations. 

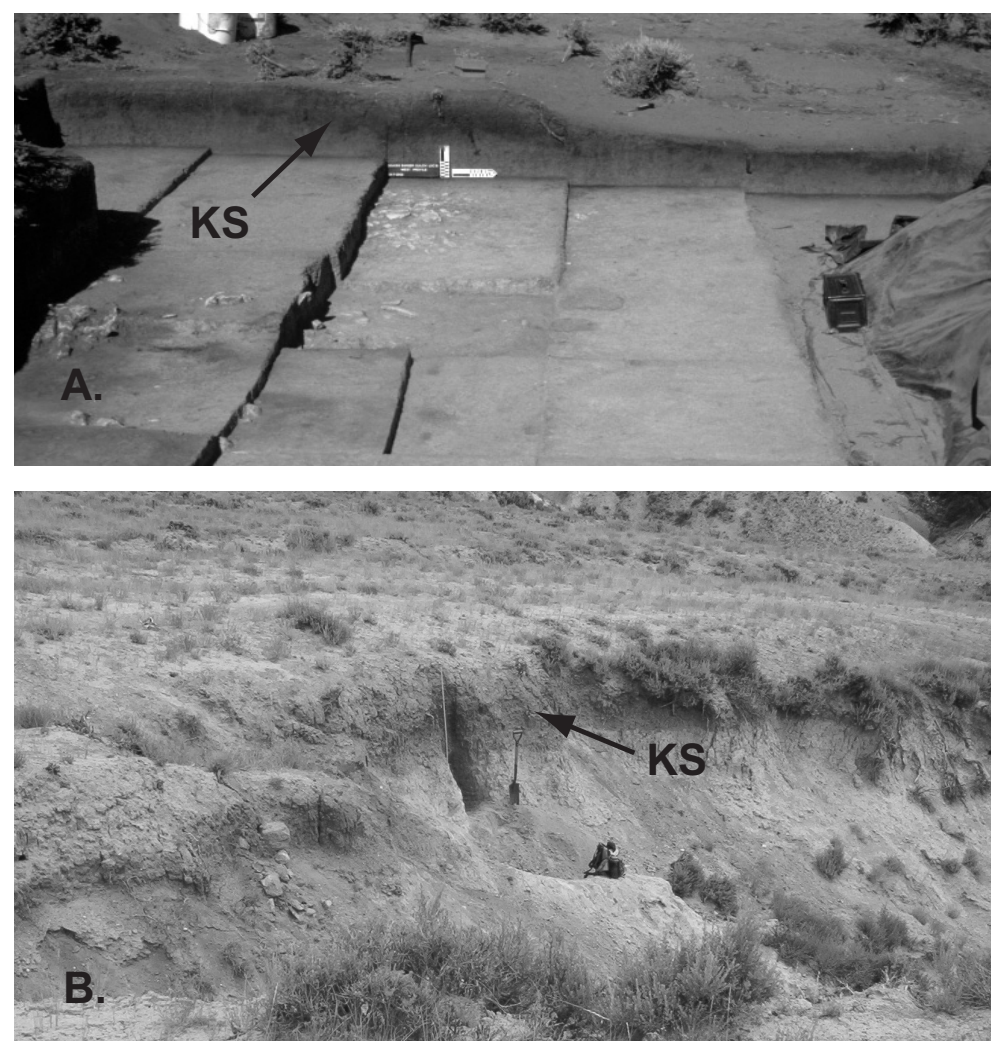

Figure 2 Examples of upland soil-stratigraphic contexts in western Middle Park. Prominent buried soil in both photographs is the Kremmling soil (KS). A) Excavation profile at the Barger Gulch Locality B Folsom site. Length of exposure is $\sim 5 \mathrm{~m}$. B) Location of Jeep Crawl Gulch profile 05-1. Shovel is approximately $1 \mathrm{~m}$ in length.

The goals of this study are threefold. First, we hope that comparisons of charcoal and SOM ${ }^{14} \mathrm{C}$ ages from the same soils will allow an assessment of the reliability and limitations of SOM ${ }^{14} \mathrm{C}$ ages in the study area. Second, we hope to establish the extent to which charcoal may or may not be redeposited on the landscape subsequent to initial deposition. Lastly, we hope the charcoal and SOM ${ }^{14} \mathrm{C}$ ages will facilitate the establishment of a preliminary chronological framework with which to interpret the upland soil-stratigraphic record of changes in hillslope character during the Holocene. We believe that our results will aid researchers in interpreting SOM ages in stratigraphic sequences from comparable environmental settings in the Rocky Mountains and elsewhere.

\section{SETTING}

Middle Park in north-central Colorado is one of several intermontane basins in the Southern Rocky Mountains (Figure 1). Elevations in the park are variable, ranging from $\sim 2300 \mathrm{~m}$ along the Colorado River to over $3960 \mathrm{~m}$ on the high peaks at its eastern edge. Our study site is restricted to western Middle Park, where the average floor elevation is about $2350 \mathrm{~m}$ and mean annual maximum and minimum temperatures in Kremmling are 12.9 and $-5.7^{\circ} \mathrm{C}$. Mean annual precipitation is $25.5 \mathrm{~cm}$, approximately $33 \%$ of which occurs as monsoonal precipitation between June and August, and snowfall between October and April contributes $\sim 42 \%$ (Western Regional Climate Center 2008). Below $2600 \mathrm{~m}$, western Middle Park is dominated by big sagebrush (Artemisia tridentata) and 
grasses (Poaceae); however, isolated groves of Douglas fir (Pseudotsuga menzieseii) and aspen (Populus tremuloides) with sagebrush understory are common on north-facing slopes. More extensive stands of Douglas fir, aspen, spruce (Picea spp.), and subalpine fir (Abies lasiocarpa) occur above $2600 \mathrm{~m}$. Much of the surficial geology in the study area consists of the Miocene Troublesome Formation, a basin fill characterized by a series of tuffaceous claystones, siltstones, and conglomerates (Izett and Barclay 1973; Izett and Obradovich 2001).

Relatively fine-grained, unconsolidated deposits derived from the Troublesome Formation primarily through sheetwash and containing buried soils are common in upland settings, typically occurring as mantles over bedrock along shoulder- and sideslopes, and in first-order valley fills. Gravels and angular cobbles occur locally and suggest some of the deposits have colluvial sources as well. Deposits on hillslopes are usually $<1 \mathrm{~m}$ thick and often unconformably overlie residual soils on bedrock or truncated Btk and/or Bk horizons formed over older sheetwash deposits; however, valley fills may reach $4 \mathrm{~m}$ in thickness at junctions of low-order tributaries. The Kremmling soil is laterally continuous in exposures for a few to several tens of meters (Figure 2), and common characteristics of the soil include: relatively dark (10YR or 7.5YR 3/2) soil A and AB horizons, often 25 to $30 \mathrm{~cm}$ in combined thickness, and displaying Stage I to I+ carbonates (after Machette 1985); conspicuous large $(\sim 0.25-0.5 \mathrm{~mm})$ charcoal fragments; and subsoil Btk horizons displaying strong structural development and Stage I to I+ carbonate development (see Table 2). In most sections, the Kremmling soil is buried by sheetwash or colluvium displaying relatively weak pedogenic development, which in turn is buried by recent laminated sheetwash with little to no evidence of pedogenic modification. The contact between the Kremmling soil and younger sheetwash and/or colluvial deposits is typically abrupt, and the number and character of soils burying the Kremmling soil varies locally, as does the depth of burial.

\section{METHODS}

Buried soils were examined and described at 5 natural exposures, 2 artificial exposures at the Barger Gulch Locality B archaeological site, and a road cut (Table 1). Soils were morphologically described, then sampled for physical and chemical characterization following Catt (1990) and Birkeland (1999), and laboratory analyses carried out following Singer and Janitsky (1986). These included: particle-size analysis using the pipette method; organic carbon content by the dichromate method; and total carbonate content using a Chittick apparatus and gas manometry.

Table 1 Summary of sample localities in western Middle Park.

\begin{tabular}{|c|c|c|c|c|c|c|c|}
\hline Profile & $\begin{array}{l}\text { Latitude } \\
\left({ }^{\circ} \mathrm{N}\right)\end{array}$ & $\begin{array}{l}\text { Longitude } \\
\left({ }^{\circ} \mathrm{W}\right)\end{array}$ & $\begin{array}{l}\text { Elevation } \\
\text { (ft) }\end{array}$ & $\begin{array}{l}\text { Slope } \\
(\%)\end{array}$ & $\begin{array}{l}\text { Aspect } \\
\left(^{\circ}\right)\end{array}$ & Setting & Dominant vegetation \\
\hline $\begin{array}{l}\text { BG Locality B } \\
\text { excavation area }\end{array}$ & 40.03267 & 106.29537 & 7620 & 5 & 335 & sideslope & sagebrush; grass \\
\hline BG 04-1 & 40.03349 & 106.29676 & 7550 & 8 & 358 & $\begin{array}{l}\text { footslope/ } \\
\text { valley fill }\end{array}$ & sagebrush; grass \\
\hline BG 05-1 & 40.03285 & 106.29593 & 7600 & 7 & 280 & $\begin{array}{l}\text { footslope/ } \\
\text { valley fill }\end{array}$ & sagebrush; grass \\
\hline CG 03-6 & 40.10889 & 106.37045 & 7870 & 8 & 226 & sideslope & sagebrush; grass \\
\hline HG 03-1 & 40.07930 & 106.34357 & 7710 & 1 & 25 & valley fill & sagebrush; grass \\
\hline JCG 05-1 & 40.08686 & 106.37242 & 7710 & 13 & 127 & sideslope & sagebrush; grass \\
\hline JCS 05-1 & 40.13358 & 106.34917 & 8020 & 14 & 30 & $\begin{array}{l}\text { footslope/ } \\
\text { valley fill }\end{array}$ & $\begin{array}{l}\text { sagebrush; service } \\
\text { berry; grass (lower } \\
\text { treeline } \sim 65 \mathrm{ft} \text { upslope) }\end{array}$ \\
\hline
\end{tabular}




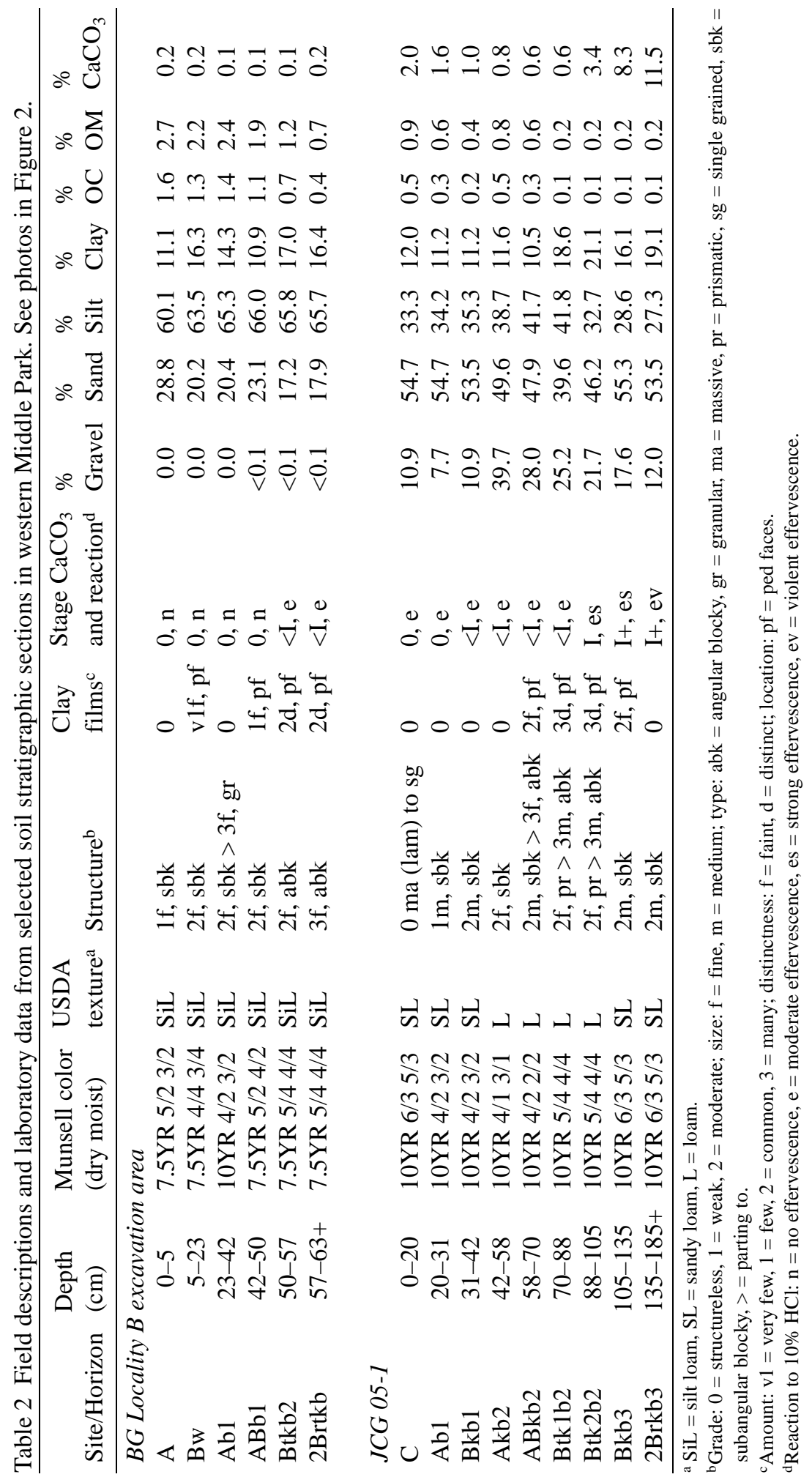


For ${ }^{14} \mathrm{C}$ dating of SOM fractions, we sampled the uppermost $10 \mathrm{~cm}$ of buried surface horizons or the entire horizon if $<10 \mathrm{~cm}$ in total horizon thickness. Charcoal samples were typically recovered as individual fragments $(\sim 0.25-0.5 \mathrm{~mm})$. Where large charcoal fragments were not observed, charcoal flecks were isolated by sieving bulk soil samples. In a prior study by McGeehin et al. (2001), ${ }^{14} \mathrm{C}$ ages of different SOM fractions from a variety of soils were compared with macrofossil ages from the same soils. They determined that $2 \mathrm{SOM}$ fractions were consistently most similar to the macrofossil ${ }^{14} \mathrm{C}$ ages: 1 ) a low-temperature $\left(400{ }^{\circ} \mathrm{C}\right)$ combustion of the $\mathrm{NaOH}$-insoluble residue fraction and 2) humic acids extracted from the $<63-\mu \mathrm{m}$ fraction. For the Middle Park samples, we dated humic acid and low-temperature residue fractions on the $<125-\mu \mathrm{m}$ size fraction.

Samples were dried and crushed, passed through a $125-\mu \mathrm{m}$ sieve, and treated with a concentrated $\mathrm{NaCl}$ solution $(\sim 1.3 \mathrm{~g} / \mathrm{mL})$ to remove fine particulate organic matter. Soil and charcoal samples were given an acid-alkali-acid (AAA) pretreatment consisting of a $1 \mathrm{M} \mathrm{HCl}\left(2 \mathrm{hr}, 60{ }^{\circ} \mathrm{C}\right), 0.1 \mathrm{M}$ $\mathrm{NaOH}$ (overnight, $60^{\circ} \mathrm{C}$ ), and $1 \mathrm{M} \mathrm{HCl}\left(2 \mathrm{hr}, 60^{\circ} \mathrm{C}\right)$. After centrifuging soil samples, the humic acid fraction was passed through $\mathrm{VWR}^{\circledR}$ No. 693 glass fiber filter paper, precipitated with $1 \mathrm{M} \mathrm{HCl}$, washed to a $\mathrm{pH} \sim 4$, and dried. The $\mathrm{NaOH}$-insoluble residue fraction was acidified, washed to a $\mathrm{pH}$ of $\sim 5$, and dried. The combustion protocol for both fractions follows that of McGeehin et al. (2001). With 2 exceptions, samples were measured at the NSF-Arizona AMS facility in Tucson, Arizona, USA. Sample A-13923 was measured using conventional beta emission counting at the University of Arizona Laboratory for Isotope Geochemistry, and sample Beta-173706 was measured by Beta Analytic (Miami, Florida, USA). ${ }^{14} \mathrm{C}$ ages were corrected for isotope fractionation, calibrated using Calib v 5.1 beta (Stuiver and Reimer 1993), and are presented in Table 3 in ${ }^{14} \mathrm{C}$ yr BP $(1 \sigma)$ and calibrated yr BP $(2 \sigma)$.

\section{RESULTS}

Throughout the remainder of the text, the $<125-\mu \mathrm{m}$ low-temperature $\mathrm{NaOH}$-insoluble residue fraction and the humic acid fraction are referred to as LT and HA, respectively. For most of the Kremmling soil profiles, charcoal, HA, and LT fractions are available for comparison (Table 3; Figures 4 and 5), whereas only HA fractions were dated for younger soils not producing charcoal (BG 04-1, CG 03-6, and JCG 05-1). One exception is a younger buried soil near the lower tree line that contained charcoal (JCS 05-1). For comparison, we present 4 previously published ages from the main excavation block of the Barger Gulch Locality B archaeological site (Mayer et al. 2005; Surovell et al. 2005) consisting of 2 pairs of residue and humic acid fractions isolated using standard AAA pretreatment (e.g. Abbot and Stafford 1996), combusted at $800{ }^{\circ} \mathrm{C}$, and referred to as HT and HA, respectively.

The most consistent first-order observation from these results is that charcoal ages are, in most cases, older than SOM ages, on average $880 \pm 230{ }^{14} \mathrm{C}$ yr older (Table 4). The HA fractions are $390 \pm 210{ }^{14} \mathrm{C}$ yr younger than charcoal from the same horizon, while LT samples are $1290 \pm 300$ ${ }^{14} \mathrm{C}$ yr younger than charcoal ages (Table 4; Figures 4 and 5). No charcoal was present at HG 03-1, but a Cody Complex Paleoindian projectile point was recovered in situ from the Kremmling soil (Mayer et al. 2005) approximately $10 \mathrm{~cm}$ below the depth of the SOM samples (Figure 3 ). The ${ }^{14} \mathrm{C}$ age range of the Cody Complex is constrained between 9500 and 8500 BP in North America (Holliday 2000; Pitblado 2003), and thus is substantially older than both the HA and LT ages (Table 3). In all cases, HA fractions are older than LT fractions, on average $860 \pm 140{ }^{14} \mathrm{C} \mathrm{yr}$ (Table 4). All of the ${ }^{14} \mathrm{C}$ ages from buried Kremmling surface soil horizons occur between 9000 and $4000 \mathrm{BP}$, while the buried surface horizon at JCS 05-1 produced entirely late Holocene ages (Table 3; Figures 4 and $5)$. 
Table 3 Summary of ${ }^{14} \mathrm{C}$ samples and ages from western Middle Park.

\begin{tabular}{|c|c|c|c|c|c|c|c|}
\hline Profile & Horizon & $\begin{array}{l}\text { Depth } \\
(\mathrm{cm})\end{array}$ & Lab \# & $\begin{array}{l}\text { Material } \\
\text { dated }^{\mathrm{a}}\end{array}$ & $\begin{array}{l}{ }^{14} \mathrm{C} \text { yr BP } \\
(1 \sigma)\end{array}$ & $\begin{array}{l}\text { Calendar yr BP } \\
(2 \sigma)\end{array}$ & $\begin{array}{l}\delta^{13} \mathrm{C} \\
(\% o) \\
\end{array}$ \\
\hline BG Loc. B & Ab1 & $18-23$ & AA $45657^{\mathrm{b}}$ & SOM, HT & $5178 \pm 49$ & $6020-5863$ & -25.7 \\
\hline \multirow[t]{3}{*}{ exc. area } & & & AA $45658^{b}$ & SOM, HA & $5437 \pm 45$ & $6312-6177$ & -24.6 \\
\hline & $\mathrm{Ab} 1$ & $37-42$ & AA $45655^{\mathrm{b}}$ & SOM, HT & $5890 \pm 65$ & $6886-6543$ & -24.6 \\
\hline & & & AA $45656^{\mathrm{b}}$ & SOM, HA & $6003 \pm 64$ & $6999-6675$ & -25.0 \\
\hline \multirow[t]{5}{*}{ BG 05-1 } & Akb1 & 11 & AA67875 & Charcoal & $6041 \pm 45$ & $7004-6775$ & -21.9 \\
\hline & Akb1/ABtkb1 & 22 & AA $65323^{d}$ & Charcoal & $7833 \pm 57$ & 8780-8452 & -24.0 \\
\hline & & 52 & AA67874 & harcoal & $9354 \pm 55$ & $10,718-10,411$ & -24.8 \\
\hline & & 90-97 & Beta-173706 ${ }^{\mathrm{d}}$ & Charcoal & $9640 \pm 40$ & $10,974-10,786$ & -23.0 \\
\hline & & 175 & AA68830 & Charcoal & $10,680 \pm 40$ & $12,830-12,744$ & -22.2 \\
\hline \multirow[t]{8}{*}{ BG 04-1 } & $\mathrm{Ab} 2$ & $36-45$ & AA63526 & SOM, HA & $2462 \pm 40$ & $2619-2362$ & -24.9 \\
\hline & Ab3 & $127-137$ & AA63527 & SOM, HA & $4156 \pm 49$ & $4567-4833$ & -24.9 \\
\hline & $\mathrm{Ab} 4$ & $150-152$ & AA63521 & Charcoal & $7592 \pm 53$ & $8521-8321$ & -23.7 \\
\hline & & $150-159$ & AA67284 & SOM, HA & $7430 \pm 82$ & $8389-8151$ & -24.4 \\
\hline & & & AA67281 & SOM, LT & $6435 \pm 50$ & $7429-7270$ & -25.7 \\
\hline & Ab5 & $171-173$ & AA63522 & Charcoal & $8664 \pm 55$ & $9780-9530$ & -24.0 \\
\hline & & & AA67282 & SOM, HA & $7966 \pm 58$ & $8997-8641$ & -24.4 \\
\hline & & & AA67283 & SOM, LT & $6577 \pm 50$ & $7566-7425$ & -25.1 \\
\hline \multirow[t]{5}{*}{ CG 03-6 } & $\mathrm{Ab} 1$ & $35-45$ & AA68827 & SOM, HA & $2271 \pm 43$ & $2341-2310$ & -24.8 \\
\hline & ABtkb2 & $70-75$ & AA67881 & Charcoal & $4469 \pm 55$ & $5302-4959$ & -22.3 \\
\hline & & $80-85$ & AA67275 & Charcoal & $7784 \pm 55$ & $8654-8422$ & -24.0 \\
\hline & & & AA67277 & SOM, HA & $6576 \pm 66$ & $7582-7414$ & -24.0 \\
\hline & & & AA67276 & SOM, LT & $5910 \pm 49$ & $6861-6637$ & -24.5 \\
\hline \multirow[t]{2}{*}{ HG 03-1 } & $\mathrm{Ab} 1$ & $50-55$ & AA67279 & SOM, HA & $5357 \pm 62$ & $5074-4863$ & -24.5 \\
\hline & & & AA67278 & SOM, LT & $4417 \pm 46$ & $6283-5993$ & -24.6 \\
\hline \multirow[t]{5}{*}{ JCG 05-1 } & $\mathrm{Ab} 1$ & $20-30$ & AA68829 & SOM, HA & $2470 \pm 44$ & $2714-2427$ & -25.9 \\
\hline & Akb2 & $48-50$ & AA67272 & Charcoal & $5603 \pm 42$ & $6454-6301$ & -23.7 \\
\hline & & $42-52$ & AA67273 & SOM, LT & $4258 \pm 45$ & $6210-5986$ & -23.9 \\
\hline & & & AA67274 & SOM, HA & $5308 \pm 47$ & 4892-4697 & -23.2 \\
\hline & ABkb2, base & $70-72$ & A-13923 & Charcoal & $8950 \pm 135$ & $10,302-9603$ & -24.6 \\
\hline \multirow[t]{5}{*}{ JCS 05-1 } & $\mathrm{Ab} 1$ & $22-23$ & AA67268 & Charcoal & $244 \pm 38$ & $330-145$ & -24.9 \\
\hline & $\mathrm{Ab} 2$ & $56-57$ & AA67267 & Charcoal & $1550 \pm 44$ & $1531-1350$ & -25.2 \\
\hline & & $48-58$ & AA67271 & SOM, HA & $1563 \pm 40$ & $1537-1368$ & -25.1 \\
\hline & & & AA67270 & SOM, LT & $1111 \pm 39$ & 1090-933 & -25.4 \\
\hline & BEb2 & $80-81$ & AA67266 & Charcoal & $3031 \pm 44$ & 3359-3138 & -22.3 \\
\hline
\end{tabular}

a Fraction abbreviations: $\mathrm{SOM}=$ soil organic matter, $\mathrm{HT}=$ high-temperature residue, $\mathrm{HA}=$ humic acid, $\mathrm{LT}=$ low-temperature residue.

${ }^{\mathrm{b}}$ Originally published by Surovell et al. (2005)

${ }^{\mathrm{c}}$ Originally published by Mayer et al. (2007)

${ }^{\mathrm{d}}$ Originally published by Mayer et al. (2005)

Table 4 Summary of offsets between ${ }^{14} \mathrm{C}$ ages of charcoal and soil organic matter.

\begin{tabular}{lcl}
\hline Fractions $^{\mathrm{a}}$ & Offset $\left({ }^{14} \mathrm{C} \mathrm{yr}\right)^{\mathrm{b}}$ & Comparisons \\
\hline Charcoal - (HA and LT) & $880 \pm 230$ & $n=10$ \\
Kremmling soil only & $1130 \pm 240$ & $n=8$ \\
Charcoal - HA & $390 \pm 210$ & $n=5$ \\
Charcoal - LT & $1290 \pm 300$ & $n=5$ \\
HA - LT & $860 \pm 140$ & $n=6$ \\
HA - (LT and HT) & $710 \pm 150$ & $n=8$ \\
\hline
\end{tabular}

${ }^{\mathrm{a}}$ Fraction abbreviations: $\mathrm{HA}=$ humic acid, $\mathrm{LT}=$ low-temperature residue, $\mathrm{HT}=$ high-temperature residue ${ }^{b}$ Offsets are weighted averages calculated using equations in Burr et al. (2007). 


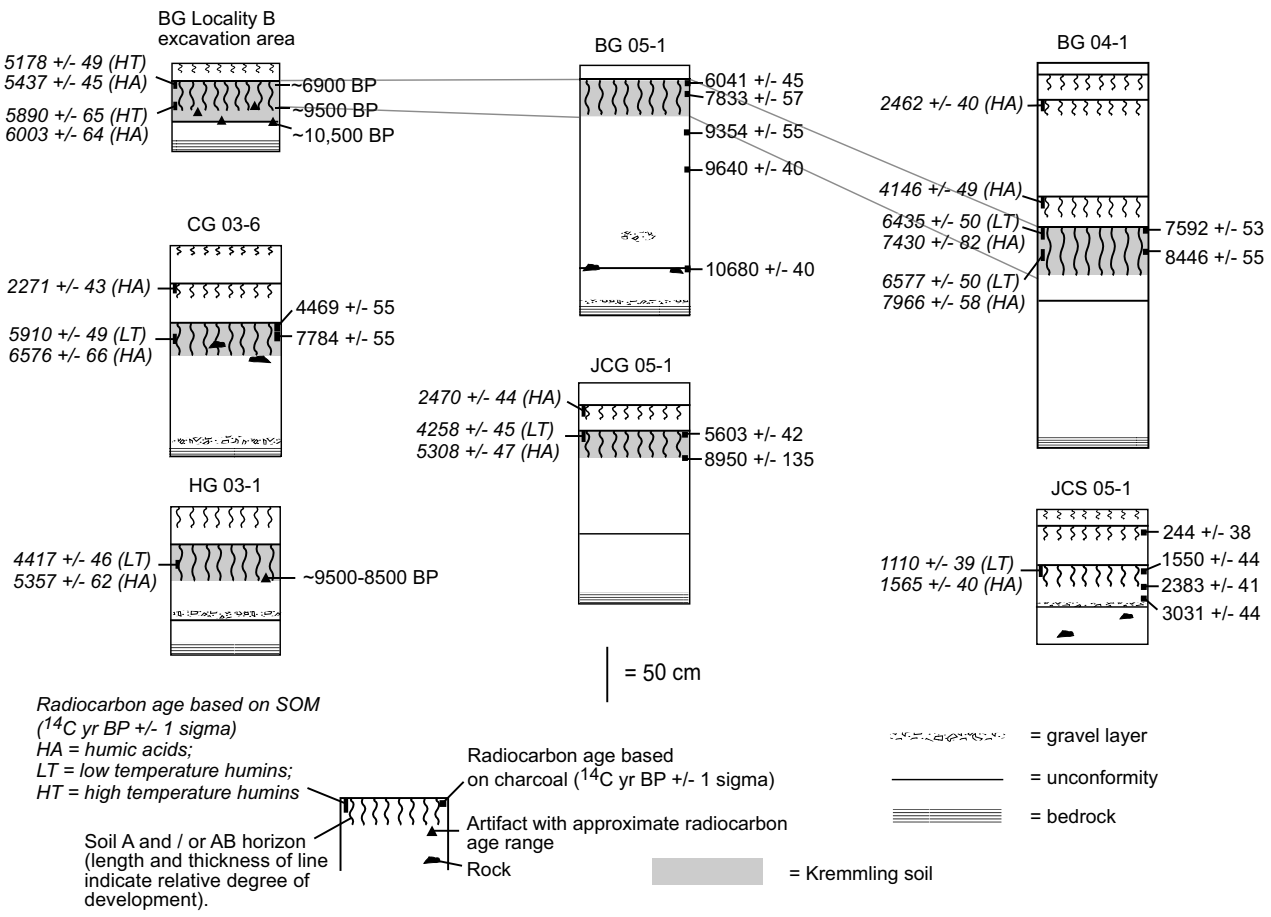

Figure $3{ }^{14} \mathrm{C}$-dated soil stratigraphic sections from western Middle Park. See Table 1 for a summary of sample locations and Table 3 for summary of ${ }^{14} \mathrm{C}$ sample information.

The HT and HA samples from the Kremmling soil in the main block of the Barger Gulch excavation area show the same relationship as the LT and HA fractions, though they are in closer agreement relative to most SOM pairs (Table 4, Figures 4 and 5). While no charcoal samples were recovered in direct association with the SOM samples, the Kremmling soil A horizon in the Barger Gulch Locality B excavation area produced charcoal ages of $\sim 9500 \mathrm{BP}$ and $\sim 6900 \mathrm{BP}$ from lower and upper samples, respectively (Mayer et al. 2005; Surovell et al. 2005). The HT and HA SOM ${ }^{14} \mathrm{C}$ ages from the Kremmling soil Ab horizon are younger than charcoal samples from adjacent levels, but they are stratigraphically consistent within fractions (Figure 4). The Kremmling soil at Locality B encases a Folsom archaeological component (Surovell and Waguespack 2007) concentrated below the $\mathrm{Ab}$ horizon and probably associated with an unconformity (Surovell et al. 2005). Charcoal recovered from Folsom hearths below the Ab horizon at Locality B produced ${ }^{14} \mathrm{C}$ ages of $\sim 10,470 \mathrm{BP}$ and $\sim 10,770$ BP (Surovell et al. 2005), consistent with dated Folsom components elsewhere in North America (Haynes 1992; Holliday 2000).

SOM fractions from BG 04-1 represent samples from upper (Ab4) and lower (Ab5) portions of a cummulic facies of the Kremmling soil (Figures 3 and 4). While they are stratigraphically consistent within fractions, the lower LT sample is younger than the overlying HA sample. Both of the HA samples are in relatively good agreement with the charcoal ages (Figure 4). As stated above, SOM samples from the Barger Gulch Locality B excavation area produced ${ }^{14} \mathrm{C}$ ages that are stratigraphically consistent both within and between the HA and HT fractions (Figures 3 and 4), but both pairs are substantially younger than charcoal samples from similar stratigraphic levels. 


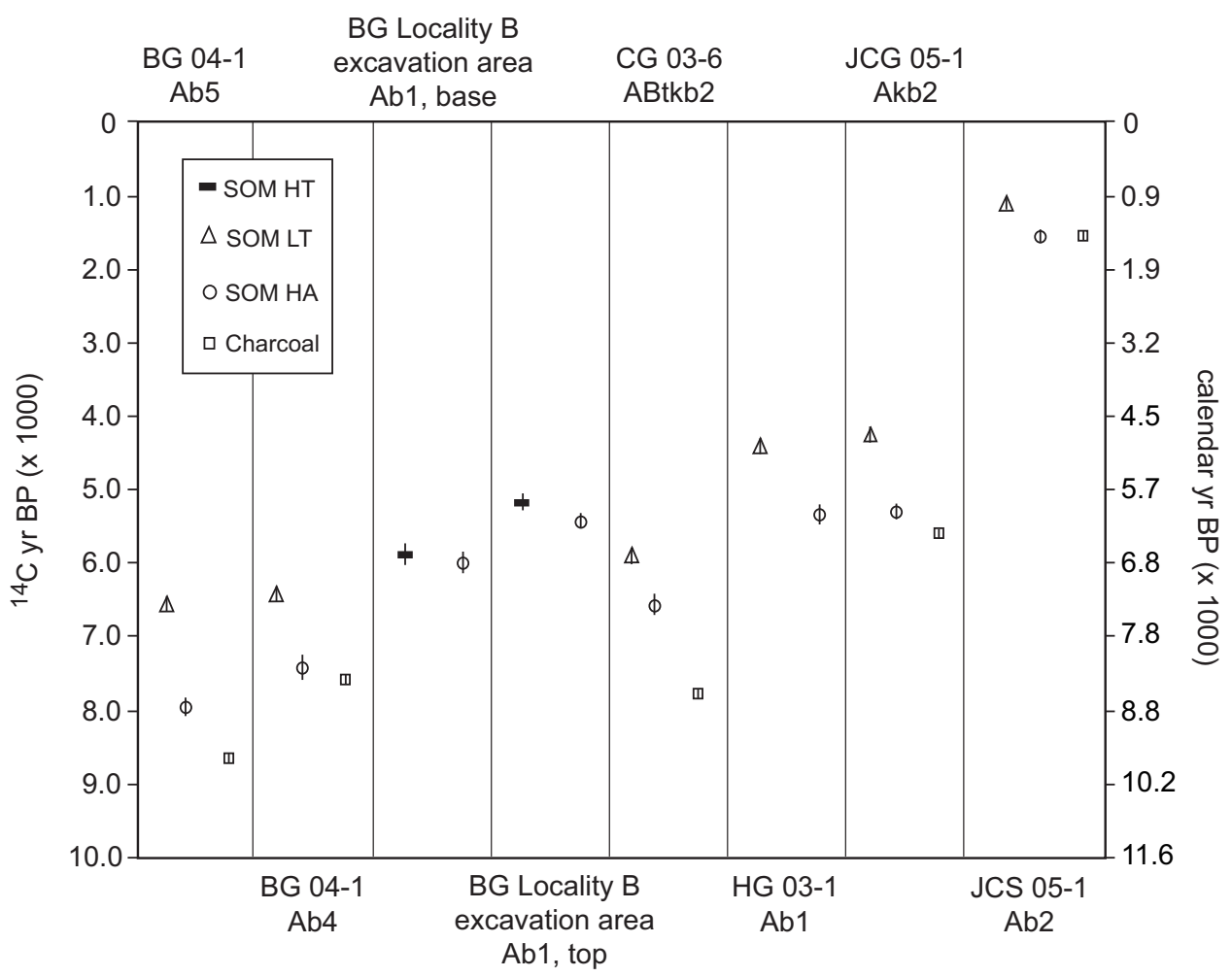

Figure 4 Comparisons of ${ }^{14} \mathrm{C}$ ages of paired soil organic matter (SOM) samples and charcoal from buried soil $\mathrm{A}$ and/or $\mathrm{AB}$ horizons. $\mathrm{HT}=$ high-temperature residue, $\mathrm{LT}=$ low-temperature residue, $\mathrm{HA}=$ humic acids. Vertical bars represent $1 \sigma$. Several error bars are smaller than symbols for ${ }^{14} \mathrm{C}$ ages. See Table 3 for summary of ${ }^{14} \mathrm{C}$ sample information.

No other Kremmling soil profiles allow additional assessment of the stratigraphic relationships of SOM fractions; however, in profiles CG 03-6 and JCG 05-1, ages of the LT and HA fractions are consistent with ages of overlying and/or underlying charcoal ages (Figure 3). Where multiple, charcoal-derived ${ }^{14} \mathrm{C}$ ages are available from individual Kremmling soil profiles (BG 04-1, BG 05-1, JCG 05-1, and CG 03-6), all are in good stratigraphic agreement with no apparent inversions, even over relatively short depth intervals (Figure 3 ). The charcoal chronology from JCS $05-1$ is also coherent (Figure 3). Charcoal was not observed in any of the younger soils in deposits burying the Kremmling soil, and thus no charcoal ${ }^{14} \mathrm{C}$ ages are available for comparison with $\mathrm{SOM}{ }^{14} \mathrm{C}$ ages. However, HA ${ }^{14} \mathrm{C}$ ages from younger soils at BG 04-1, CG 03-6, and JCG 05-1 are stratigraphically consistent with charcoal and SOM ages from the underlying Kremmling soil (Figure 3).

\section{DISCUSSION}

\section{Reliability of ${ }^{14} \mathrm{C}$ Ages of Soil Organic Matter}

Our primary goal in this study is to establish the reliability and/or limitations of ${ }^{14} \mathrm{C}$ ages based on SOM from buried Holocene soils in Middle Park, Colorado. As summarized above, problems of dating buried soils generally involve the duration of soil formation (i.e. the pre-burial MRT) and the extent to which the soils were isolated from contamination after burial. The longer a soil forms, the greater the potential discrepancy in SOM ${ }^{14} \mathrm{C}$ ages relative to the "true" age of the onset of pedogen- 


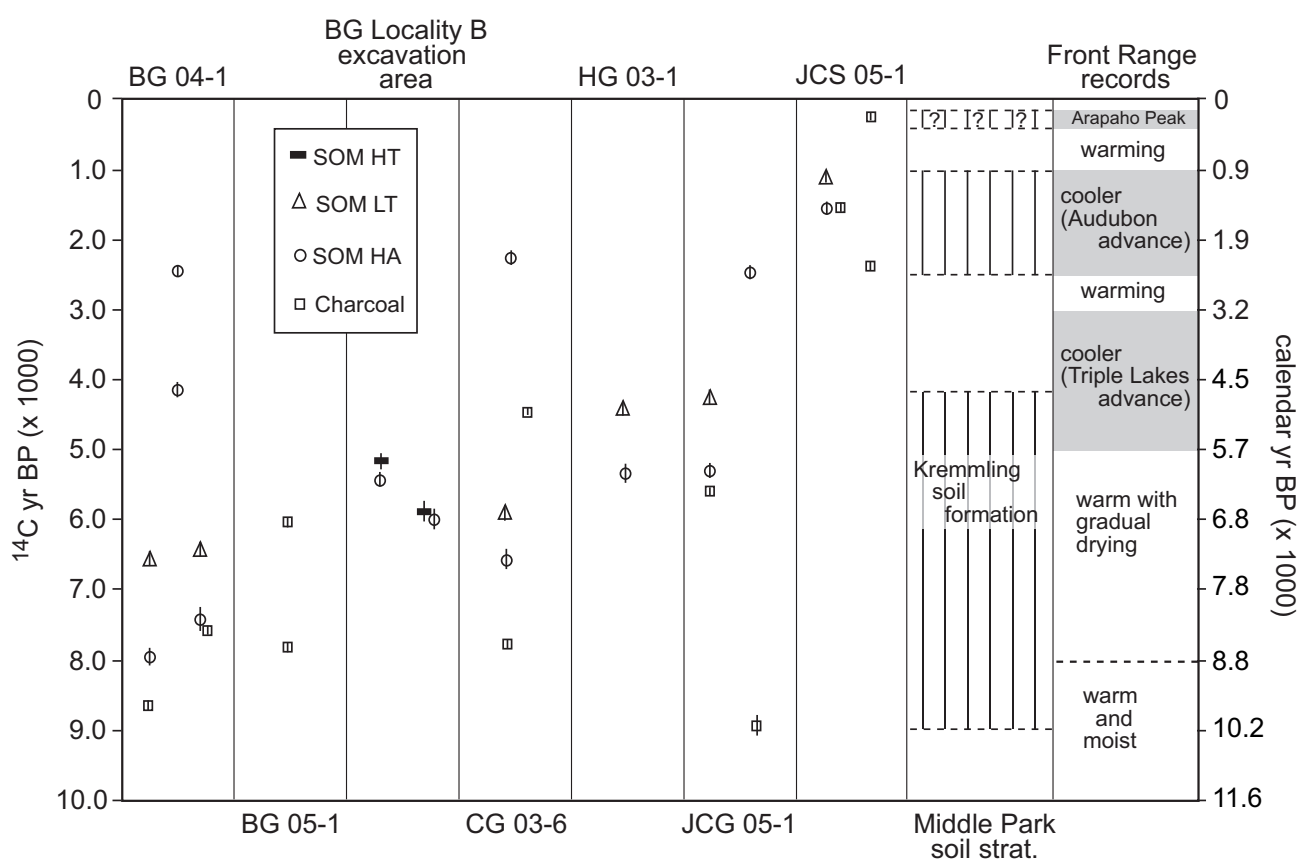

Figure $5{ }^{14} \mathrm{C}$ ages from buried soils in western Middle Park, interpretation of Middle Park soil stratigraphy, and summary of paleoenvironmental records from north-central Colorado. Vertical lines in Middle Park soil stratigraphy column represent periods of relative landscape stability and soil formation, while white areas represent erosion and/or deposition. Dashed lines indicate uncertainties in the timing of onset and ending of records. See text for references of paleoenvironmental records. $\mathrm{HT}=$ high-temperature residue, $\mathrm{LT}=$ low-temperature residue, $\mathrm{HA}=$ humic acids. Vertical bars associated with ${ }^{14} \mathrm{C}$ sample symbols represent $1 \sigma$. Several error bars are smaller than symbols for ${ }^{14} \mathrm{C}$ ages. See Table 3 for summary of ${ }^{14} \mathrm{C}$ information.

esis. This may also result in fractions of soil organic matter with different rates of turnover displaying disparate ${ }^{14} \mathrm{C}$ ages (e.g. Trumbore and Zheng 1996; Leavitt et al. 1996; Paul et al. 2001). There are at least 2 potential sources by which younger carbon can enter the soil once it is buried, especially where depth of burial is shallow, as in the case of most of the Middle Park profiles: rootlet penetration and decomposition, and soluble humic acids translocated by soil water. Accordingly, the soils examined here are buried, but probably not isolated from surface soil processes (Schaetzel and Sorenson 1987).

Charcoal and SOM samples producing early to middle Holocene ${ }^{14} \mathrm{C}$ ages and Paleoindian archaeological material occur in the Kremmling soil in relatively shallow contexts, often buried by a meter or less of younger sediments (Figure 3). Simple linear regression reveals no strong relationship between the offsets of HA and LT ${ }^{14} \mathrm{C}$ ages and depth of burial $\left(R^{2}=0.435\right)$. An even weaker relationship $\left(R^{2}=0.298\right)$ exists between the offsets in ${ }^{14} \mathrm{C}$ ages of charcoal and the LT SOM fraction and depth of burial, and there is no correlation between offsets in charcoal and HA SOM fraction ${ }^{14} \mathrm{C}$ ages and depth of burial $\left(R^{2}=0.036\right)$. Moreover, we are confident that our pretreatment effectively removed modern rootlets. Likewise, the general agreement between the $\mathrm{HA}$ and charcoal ${ }^{14} \mathrm{C}$ ages in profiles BG 04-1 (upper sample), JCS 05-1, and, to a lesser extent, JCG 05-1 suggest that sorption of younger humic acids is not a likely source of contamination. We believe that the differences between ${ }^{14} \mathrm{C}$ ages of charcoal and SOM fractions observed in the Middle Park samples, as well as the consistent offsets between the HA and LT fractions, are a function of the duration of pedogenesis and the different residence times of the SOM fractions dated. 
The concept of mean residence time in ${ }^{14} \mathrm{C}$ dating of SOM is aptly likened to a "weighted mean" of the ages of the many components of SOM (Schaetzel and Anderson 2005:606-610). As carbon is continually added to the soil during pedogenesis, soils forming over longer intervals have greater potential for discrepancies between the ages of the fractions comprising SOM. All Kremmling soil profiles produced ${ }^{14} \mathrm{C}$ ages that suggest pedogenesis occurred over several millennia, and the offsets between the LT and HA fractions can be interpreted as reflecting more active and recalcitrant fractions of SOM prior to burial. Conversely, the shorter the episode of soil formation, the more likely SOM fractions are to be of similar age, a relationship well illustrated by profile JCS $05-1$ where ${ }^{14} \mathrm{C}$ ages of charcoal and SOM fractions are in relatively good agreement. The lower buried A horizon at JCS $05-1$ produced nearly identical HA and charcoal ${ }^{14} \mathrm{C}$ ages, while the LT age is younger (Table 3; Figures 4 and 5). Pedogenesis of the lower buried soil at JCS 05-1, based on charcoal ages, did not begin until sometime after $\sim 3031 \mathrm{BP}$ (Figure 3), and probably lasted for $<1500{ }^{14} \mathrm{C}$ yr. The duration of soil formation is thus substantially shorter than that of the Kremmling soil, which probably explains the relative agreement in SOM ages of the younger soil. Kremmling soil profiles show relatively strong B horizon development (Table 2 and Mayer, unpublished data), likely reflecting a long period of relative land surface stability and, in part, accounting for the $1130 \pm 240{ }^{14} \mathrm{C}$ yr average offset between charcoal and SOM ${ }^{14} \mathrm{C}$ ages (Table 4). Finally, the agreement between the HA and charcoal ${ }^{14} \mathrm{C}$ age from the same epipedon at JCS 05-1 supports the contention that charcoal associated with buried surface horizons probably accumulated on a relatively stable surface during soil formation.

The consistent direction of offset in the ${ }^{14} \mathrm{C}$ ages of the LT fraction relative to the charcoal and HA fraction ${ }^{14} \mathrm{C}$ ages observed here differs slightly from the results of McGeehin et al. (2001), where the LT fraction tended to be older than ages of macrofossils and HA fractions. This could be a function of local environmental factors affecting organic matter decomposition and humus formation. The same relationship we observe between the LT and HA fractions occurs in the HT and HA fractions from the Kremmling soil at the Barger Gulch excavation profile (Table 4, Figures 3 and 4), albeit to a lesser extent. The HT ${ }^{14} \mathrm{C}$ ages may be in closer agreement with the HA ages (i.e. older than the LT ages) because of contributions of clay-derived carbon resulting from the $800{ }^{\circ} \mathrm{C}$ combustion, considered by McGeehin et al. (2001) to be a significant factor in reducing the accuracy of age determinations for soils and sediments. The contribution may be low in the case of the samples from Barger Gulch, as clay content is $<15 \%$ of the particle-size distribution of the Kremmling soil Ab horizon in the main block of the excavation area (Table 3).

\section{Reliability of Charcoal ${ }^{14} \mathrm{C}$ Age}

We consider the overall stratigraphic agreement of the charcoal ${ }^{14} \mathrm{C}$ ages (Figure 3 ) as indicating that wood has a relatively short residence time on this landscape. Transport and down-slope deposition of charcoal probably occurred soon after burn events, and thus charcoal occurring in subsoil horizons is a fairly accurate representation of the age of deposition. Reworking of older charcoal into younger sediments appears to be of little significance, at least in the profiles examined here. We interpret charcoal associated with buried $\mathrm{A}$ and/or $\mathrm{AB}$ horizons to represent accumulation during relative landscape stability and soil formation (i.e. slow to negligible rates of deposition). This is supported by results from profiles BG 04-1, BG 05-1, CG 03-6, JCG 05-1, and JCS 05-1, where charcoal samples separated by a few tens of centimeters span one to several millennia (Figure 3), indicating accumulation on a relatively stable surface. Because of the amount and robust nature of charcoal common to early and middle Holocene soils and sediments in Middle Park, we suspect that future work may demonstrate that recycling of older charcoal into late Holocene deposits does in fact occur. 


\section{Interpretation of Charcoal and SOM ${ }^{14} \mathrm{C}$ Ages from Buried Soils in Middle Park}

Based on the previous discussion of ${ }^{14} \mathrm{C}$ ages of charcoal and SOM from buried soils in Middle Park, we can establish some constraints for interpreting episodes of erosion, surface stability, and environmental change. ${ }^{14} \mathrm{C}$ ages of charcoal occurring below buried $\mathrm{A}$ and $\mathrm{AB}$ horizons (i.e. in $\mathrm{B}$ and/or $\mathrm{C}$ horizons) are considered minimum ages for the onset of deposition and maximum ages for the onset of pedogenesis in the deposit. This is based on the assumption that charcoal is integrated into sediments during deposition and is not intrusive, with pedogenesis commencing after deposition sufficiently slowed. ${ }^{14} \mathrm{C}$ ages from buried $\mathrm{A}$ and/or $\mathrm{AB}$ horizons based on $\mathrm{HA}$ fractions are consistently older than LT fractions, and the HA fractions must include an older component of organic matter. However, the HA fraction is not representative of organic matter derived entirely from incipient soil formation, and instead represents an average of organic matter derived from the onset of pedogenesis until a soil is buried. ${ }^{14} \mathrm{C}$ ages of $\mathrm{HA}$ fractions are thus interpreted to represent minimum ages for the onset of pedogenesis and relative landscape stability. This is also true for ages derived from charcoal fragments occurring in $\mathrm{A}$ and/or $\mathrm{AB}$ horizons, interpreted to represent accumulation on a stable surface. The LT fractions consistently produce younger ${ }^{14} \mathrm{C}$ ages than HA fractions, implying the LT fractions include a younger component of SOM. Inasmuch as the limited comparisons allow, ${ }^{14} \mathrm{C}$ ages of the LT fractions are consistent with overlying charcoal ages and do not appear to reflect postburial additions of carbon, and are thus more representative of maximum ages for burial than HA fractions. A soil was likely forming at the surface until at least the age derived on an LT fraction, with burial occurring sometime after. These interpretations are consistent with the conclusions of others in previous studies comparing SOM ${ }^{14} \mathrm{C}$ ages (e.g. Haas et al. 1986; Martin and Johnson 1995).

\section{Upland Holocene Soil-Stratigraphic Records in Middle Park}

The ${ }^{14} \mathrm{C}$-dated upland soil stratigraphy in Middle Park provides a relatively detailed history of changes in the character of hillslopes during the Holocene (Figure 5). The truncated pre-Kremmling soils buried by Kremmling soil parent material reflect erosion and valley filling occurring by at $\sim 10,000 \mathrm{BP}$ and continuing until shortly before $\sim 9000 \mathrm{BP}$, based on lower ages from the Kremmling soil and bracketing ages in the Barger Gulch drainage (Mayer et al. 2007). We speculated previously that summer convective storms associated with an intensified monsoon (e.g. Markgraf and Scott 1981; Friedman et al. 1988) resulted in considerable erosion and geomorphic instability in Middle Park during the early Holocene (Mayer et al. 2007). This contention appears to be substantiated by the truncated pre-Kremmling soils (Figure 5).

The Kremmling soil reflects a long period of geomorphic stability in upland settings between 9000 and 4500 BP (Figure 5). The onset of Kremmling soil formation at 9000 BP (Figure 5) occurred during a period when cirques in the Front Range were largely free of ice (Benedict 1973), when upper tree line had expanded to elevations higher than at present (Benedict 1985, 2005; Short 1985; Doerner 2007), and when summer temperatures were probably warmer than at present (Elias 1985, 1996). After $\sim 8000 \mathrm{BP}$, conditions in north central Colorado were apparently becoming increasingly dry (Feiler et al. 1997; Vierling 1998; Doerner 2007), which may be reflected in Kremmling soil profiles by the transformation of Bt horizons to Btk horizons and imprinting of carbonates over former surface horizons.

The common occurrence of intact Kremmling soil $\mathrm{A}$ and $\mathrm{AB}$ horizons producing ${ }^{14} \mathrm{C}$ ages between approximately 9000 and $4500 \mathrm{BP}$ suggests that little erosion occurred in response to drying during the middle Holocene. While erosion in upland settings in western Middle Park likely occurred during the early Holocene, these areas were apparently largely stable during the middle Holocene; however, erosion occurring locally sometime after $\sim 6450 \mathrm{BP}$ but prior to $\sim 4150 \mathrm{BP}$ is indicated at 
BG 04-1 (Figure 3). Soil formation during the early and middle Holocene was also occurring in cirques in the Front Range (Benedict 1981, 1985, 2005). The latter part of Kremmling soil formation between 5000 and 4000 BP (Figure 5) overlaps with the onset of Neoglacial cooling reflected in glacial (Benedict 1973, 1985), fossil insect (Elias 1985, 1996), and palynological (Short 1985, Feiler et al. 1997, Doerner 2007) records from north-central Colorado (Figure 5).

Post-Kremmling soil erosion in Middle Park between 4000 and 2500 BP (Figure 5) generally coincides with evidence for a return to warmer conditions, as inferred by the absence of evidence for cirque glaciation in the Front Range (Benedict 1973, 1985). Evidence for warming in the Front Range beginning at 23000 BP is also reported by Elias $(1985,1996)$ and Doerner $(2007)$ from fossil insect and pollen assemblages, respectively. Hillslope erosion between 3500 and $2500 \mathrm{BP}$ is responsible for burial of the Kremmling soil in several profiles examined in this study.

Soil formation in Middle Park between 2500 and 1000 BP (Figure 5) is coeval with Audubon glaciation in the Front Range (Benedict 1973, 1985). Fossil insect assemblages indicate a return to cooler conditions at 2000 BP (Elias 1985, 1996), while palynological evidence (Doerner 2007) indicates cooling beginning slightly later at $\sim 1500$ BP. A single soil profile (JCS 05-1) provides constraints on the latest Holocene events in the study area. Erosion occurring sometime after $\sim 110 \mathrm{BP}$, but before $\sim 244$ BP, overlaps with a return to warmer conditions and glacial recession in the Front Range (Figure 5), while stability and soil formation at JCS $05-1$ occurring by at least 244 BP falls within the Arapaho Peak advance (Benedict 1973, 1985). In many of the profiles examined here, surficial deposits characterized by laminated sheetwash displaying little to no evidence for soil formation likely reflect hillslope erosion occurring since $1000 \mathrm{BP}$, probably during the past few centuries.

\section{CONCLUSIONS}

Our goals in this study were to establish 1) the reliability and limitations of ${ }^{14} \mathrm{C}$ ages based on charcoal and SOM from buried soils in Middle Park; 2) the extent to which charcoal may or may not be reworked on the landscape; and 3) the timing of changes in the character of hillslopes during the Holocene as reflected in upland soil-stratigraphic records.

Comparisons between ${ }^{14} \mathrm{C}$ ages from buried surface horizons suggest that charcoal and SOM ages provide reasonable estimates for the timing of geomorphic change during the Holocene in Middle Park. Moreover, ages based on charcoal and HA fractions of SOM can be interpreted as minimum ages for the onset of soil formation and landscape stability. In all cases, HA fractions are older than LT ages, suggesting that, at least in this environment, they reflect more recalcitrant and labile fractions of SOM prior to burial. Our comparisons of SOM and charcoal ages indicate HA ages from buried soils where charcoal is absent can be interpreted as accurately reflecting minimum ages for the onset of pedogenesis, while LT fractions are interpreted as maximum ages for deposition of sediments burying soils. Finally, ${ }^{14} \mathrm{C}$ ages based on charcoal are stratigraphically consistent, suggesting that wood did not have a long residence time on the Middle Park landscape and that charcoal appears to undergo little recycling as a result of erosion and redeposition.

Upland soil-stratigraphic records are important archives of Holocene landscape evolution in Middle Park, and the results presented here provide an initial picture of the geomorphic response(s) of hillslopes in a intermontane basin to environmental change during the Holocene. This work is a first step towards understanding the sensitivity of non-glaciated landscapes in the Southern Rocky Mountains to environmental changes affecting the region over the past $10 \mathrm{kyr}$. Future work in Middle Park will focus on characterizing the relationship between vegetation change and geomorphic response over Holocene timescales. 


\section{ACKNOWLEDGMENTS}

This research was partly supported by an NSF-IGERT Fellowship in Archaeological Science from the University of Arizona Department of Anthropology, Burt S Butler and Maxwell Short scholarships from the University of Arizona Department of Geosciences, and a Geological Society of America Graduate Student Research Grant (to JHM). Garland Spears aided with sample combustions; Lori Hewitt, Sarah LaMotta, Todd Lange, and Alex Leonard kindly provided access to combustion lines; and Rich Cruz expedited sample measurement. Frank Rupp of the Bureau of Land Management, Kremmling Field Office, provided logistical and financial support. Logistical and financial support also came from the George C Frison Institute of Archaeology and Anthropology, Department of Anthropology, University of Wyoming through Nicole Waguespack and Todd Surovell. We thank Mike Daniels (Department of Geography, University of Denver) and Rick Reider (Emeritus, Department of Geography, University of Wyoming) for valuable discussion in the field. Rebecca Franklin and Andrew Kowler commented on drafts, and the critical reviews of Chris Eastoe, Bill Johnson, and Lee Nordt greatly improved the manuscript.

\section{REFERENCES}

Abbot MB, Stafford Jr TW. 1996. Radiocarbon geochemistry of modern and ancient arctic lake systems, Baffin Island, Canada. Quaternary Research 45(3):300-11.

Benedict JB. 1973. Chronology of cirque glaciation, Colorado Front Range. Quaternary Research 3(4):58499.

Benedict JB. 1981. The Fourth of July Valley: Glacial Geology and Archeology of the Timberline Ecotone. Research Report No. 2. Ward, Colorado: Center for Mountain Archeology. 139 p.

Benedict JB. 1985. Arapaho Pass, Glacial Geology and Archeology at the Crest of the Colorado Front Range. Research Report No. 3. Ward, Colorado: Center for Mountain Archeology. 197 p.

Benedict JB. 2005. Rethinking the Fourth of July Valley site: a study in glacial and periglacial geoarchaeology. Geoarchaeology 20(8):797-836.

Birkeland PW. 1999. Soils and Geomorphology. 3rd edition. New York: Oxford University Press. 430 p.

Burr GS, Donahue DJ, Tang Y, Beck JW, McHargue L, Biddulph D, Cruz R, Jull AJT. 2007. Error analysis at the NSF-Arizona AMS facility. Nuclear Instruments and Methods in Physics Research B 259(1):149-53.

Campbell CA, Paul EA, Rennie DA, McCallum KJ. 1967. Applicability of the carbon-dating method of analysis to soil humus studies. Soil Science 104:21724.

Catt JA. 1986. Soils and Quaternary Geology: A Handbook for Field Scientists. Oxford: Oxford Science Publications. 300 p.

Catt JA. 1990. Field recognition, description and spatial relationships of paleosols. Quaternary International 6:2-95.

Daniels JM. 2003. Floodplain aggradation and pedogenesis in a semiarid environment. Geomorphology 56(34):225-42.

Daniels RB, Hammer RD. 1992. Soil Geomorphology. New York: Wiley Press. 256 p.
Doerner JP. 2007. Late Quaternary prehistoric environment of the Colorado Front Range. In: Brunswig RH, Pitblado BL, editors. Frontiers in Colorado Paleoindian Archaeology: From the Dent Site to the Rocky Mountains. Boulder: University Press of Colorado. p 11-38.

Elias SA. 1985. Paleoenvironmental interpretations of Holocene insect fossil assemblages from four highaltitude sites in the Front Range, Colorado, U.S.A. Arctic and Alpine Research 17(1):31-48.

Elias SA. 1996. Late Pleistocene and Holocene seasonal temperatures reconstructed from fossil beetle assemblages in the Rocky Mountains. Quaternary Research 46(3):311-8.

Evans LJ. 1995. The use of paleosols in dating Quaternary deposits. In: Rutter NW, Catto NR, editors. Dating Methods for Quaternary Deposits. St. Johns, Newfoundland: Geological Association of Canada. p 26981.

Feiler EJ, Anderson RS, Koehler PA. 1997. Late Quaternary paleoenvironments of the White River Plateau, Colorado, U.S.A. Arctic and Alpine Research 29(1): 53-62.

Friedman I, Carrara P, Gleason J. 1988. Isotopic evidence of Holocene climatic change in the San Juan Mountains, Colorado. Quaternary Research 30(3):350-3.

Gerrard J. 1992. Soils and Geomorphology: An Integration of Pedology and Geomorphology. London: Chapman and Hall. 269 p.

Geyh MA, Roeschmann G, Wijmstra TA, Middeldorp AA. 1983. The unreliability of ${ }^{14} \mathrm{C}$ dates obtained from buried sandy Podzols. Radiocarbon 25(2):40916.

Gilet-Blein N, Marien G, Evin J. 1980. Unreliability of ${ }^{14} \mathrm{C}$ dates from organic matter of soils. Radiocarbon 22(3):919-22.

Goh KM. 1980. Dynamics and stability of soil organic matter. In: Theng BKG, editor. Soil with Variable 
Change. Christchurch: New Zealand Society of Soil Science. p 373-93.

Goldberg, P, Macphail RI. 2006. Practical and Theoretical Geoarchaeology. Oxford: Blackwell Publishing. $487 \mathrm{p}$.

Haas H, Holliday VT, Stuckenrath R. 1986. Dating of Holocene stratigraphy with soluble and insoluble organic fractions at the Lubbock Lake archaeological site, Texas: an ideal case study. Radiocarbon 28(2A): $473-85$.

Haynes Jr CV. 1992. Contributions of radiocarbon dating to the geochronology of the peopling of the New World. In: Taylor RA, Long A, Kra RS, editors. Radiocarbon After Four Decades. New York: SpringerVerlag; Tucson: Radiocarbon. p 355-74.

Holliday VT. 1994. The "State Factor" approach in geoarchaeology. In: Amundson R, editor. Factors of Soil Formation: A Fiftieth Anniversary Retrospective. Madison, Wisconsin, USA: Soil Science Society of America. p 65-86.

Holliday VT. 2000. The evolution of Paleoindian geochronology and typology on the Great Plains. Geoarchaeology 15(3):227-90.

Holliday VT. 2004. Soils in Archaeological Research. New York: Oxford University Press. 448 p.

Holliday VT. 2006. A history of soil-geomorphology in the United States. In: Warkenton BP, editor. Footprints in the Soil: People and Ideas in Soil History. Amsterdam: Elsevier Press. p 187-254.

Holliday VT, Haynes Jr CV, Hofman JL, Meltzer DJ. 1994. Geoarchaeology and geochronology of the Miami (Clovis) site, southern High Plains of Texas. Quaternary Research 41(2):234-44.

Izett GA, Barclay CSV. 1973. Geologic map of the Kremmling 15-minute quadrangle, Grand County, Colorado. Washington, DC: United States Government Printing Office.

Izett GA, Obradovich JD. 2001. ${ }^{40} \mathrm{Ar} /{ }^{39} \mathrm{Ar}$ ages of Miocene tuffs in basin-fill deposits (Santa Fe Group, New Mexico, and Troublesome Formation, Colorado) of the Rio Grande Rift System. The Mountain Geologist 38:77-86.

Jenny H. 1941. Factors of Soil Formation: A System of Quantitative Pedology. New York: McGraw-Hill. $324 \mathrm{p}$.

Johnson WC, Willey KL. 2000. Isotopic and rock magnetic expression of environmental change at the Pleistocene-Holocene transition in the central Great Plains. Quaternary International 67(1):89-106.

Kornfeld M, Frison GC. 2000. Paleoindian occupation of the High Country: the case of Middle Park, Colorado. Plains Anthropologist 45(172):129-53.

Kornfeld M, Frison GC, Larson ML, Miller JC, Saysette J. 1999. Paleoindian bison procurement and paleoenvironments in Middle Park of Colorado. Geoarchaeology 14(7):655-74.

Leavitt SW, Follett RF, Paul EA. 1996. Estimation of slow- and fast-cycling organic carbon pools from $6 \mathrm{~N}$ $\mathrm{HCl}$ hydrolysis. Radiocarbon 38(2):231-9.

Machette MN. 1985. Calcic soils and calcretes of the southwestern United States. In: Weide DL, editor. Soils and Quaternary Geology of the Southwestern United States. Boulder, Colorado, USA: Geological Society of America. p 1-21.

Mandel RD. 1992. Soils and Holocene landscape evolution in central and southwestern Kansas: implications for archaeological research. In: Holliday VT, editor. Soils and Archaeology: Landscape Evolution and Human Occupation. Washington, DC: Smithsonian Institution Press. p. 41-100.

Mandel RD. 1995. Geomorphic controls of the Archaic record in the Central Plains of the United States. In: Bettis III EA, editor. Archaeological Geology of the Archaic Period in North America. Boulder, Colorado, USA: Geological Society of America. p 37-66.

Markgraf V, Scott L. 1981. Lower timberline in central Colorado during the past 15,000 years. Geology $9(5)$ : 231-4.

Martin CW, Johnson WC. 1995. Variation in radiocarbon ages of soil organic matter fractions from late Quaternary buried soils. Quaternary Research 43(2):232-7.

Matthews JA. 1980. Some problems and implications of ${ }^{14} \mathrm{C}$ dates from a podzol buried beneath an end moraine at Haugabreen, southern Norway. Geografiska Annaler 62:185-208.

Matthews JA. 1985. Radiocarbon dating of surface and buried soils: principles, problems, and prospects. In: Richards KS, Arnett RR, Ellis S, editors. Geomorphology and Soils. London: George Allen and Unwin. p 269-88.

Mayer JH, Surovell TA, Waguespack NM, Kornfeld M, Reider RG, Frison GC. 2005. Paleoindian environmental change and landscape response in Barger Gulch, Middle Park, Colorado. Geoarchaeology 20(6):599-625.

Mayer JH, Waguespack NM, Surovell TA, Daniels JM. 2007. Paleoindian geoarchaeology of the Barger Gulch area, Middle Park, Colorado. In: Raynolds RG, editor. Roaming the Rocky Mountain Environs: Geological Society of America Field Guide 10. Boulder, Colorado, USA: Geological Society of America. p 79-99.

McGeehin J, Burr GS, Jull AJT, Reines D, Gosse J, Davis PT, Muhs D, Southon JR. 2001. Stepped-combustion ${ }^{14} \mathrm{C}$ dating of sediment: a comparison with established techniques. Radiocarbon 43(2A):255-61.

Nordt L. 2004. Late quaternary alluvial stratigraphy of a low-order tributary in central Texas, USA and its response to climate and sediment supply. Quaternary Research 62(3):289-300.

Paul EA, Collins HP, Leavitt SW. 2001. Dynamics of resistant soil carbon of Midwestern agricultural soils measured by naturally occurring ${ }^{14} \mathrm{C}$ abundance. Geoderma 104(3-4):239-56. 
Pitblado BL. 2003. Late Paleoindian Occupation of the Southern Rocky Mountains: Early Holocene Projectile Points and Land Use in the High Country. Boulder, Colorado, USA: University Press of Colorado. $292 \mathrm{p}$.

Polach HA, Costin AB. 1971. Validity of soil organic matter radiocarbon dating: buried soils in Snowy Mountains, southeastern Australia as example. In: Yaalon DH, editor. Paleopedology. Jerusalem: University of Israel Press. p 89-96.

Quade J, Forester RM, Pratt WL, Carter C. 1998. Black mats, spring-fed streams, and late-glacial-age recharge in the southern Great Basin. Quaternary Research 49(2):129-48.

Quade J, Rech JA, Betancourt JL, Latorre C, Quade B, Rylander KA, Fisher T. 2008. Paleowetlands and regional climate change in the central Atacama Desert, northern Chile. Quaternary Research 69(3):343-60.

Rawling 3rd JE, Fredlund GG, Mahan S. 2003. Aeolian cliff-top deposits and buried soils in the White River Badlands, South Dakota, USA. The Holocene 13(1): 121-9.

Schaetzl RJ, Anderson S. 2005. Soils: Genesis and Morphology. New York: Cambridge University Press. $817 \mathrm{p}$.

Schaetzl RJ, Sorenson CJ. 1987. The concept of "buried" vs. "isolated" paleosols: examples from northeastern Kansas. Soil Science 143:426-35.

Scharpenseel HW. 1971. Radiocarbon dating of soilsproblems, troubles, hopes. In: Yaalon DH, editor. $\mathrm{Pa}$ leopedology. Jerusalem: University of Israel Press. p 77-88.

Scharpenseel HW, Schiffman H. 1977. Radiocarbon dating of soils, a review. Zeitschrift fur Planzenernaehrung und Bodenkunde 140:159-74.

Short SK. 1985. Palynology of Holocene sediments, Colorado Front Range; vegetation and treeline changes in the subalpine forest. American Association of Stratigraphic Palynologists Contribution Series 16:7-29.
Singer MJ, Janitsky J. 1986. Field and Laboratory Procedures Used in a Soil Chronosequence Study, US Geological Survey Bulletin 1648. Washington, DC: U.S. Government Printing Office. 49 p.

Stuiver M, Reimer PJ. 1993. Extended ${ }^{14} \mathrm{C}$ data base and revised CALIB $3.0^{14} \mathrm{C}$ age calibration program. $R a$ diocarbon 35(1):215-30.

Surovell TA, Waguespack NM. 2007. Folsom hearthcentered use of space at Barger Gulch, Locality B. In: Brunswig RH, Pitblado BL, editors. Frontiers in Colorado Paleoindian Archaeology: From the Dent Site to the Rocky Mountains. Boulder, Colorado, USA: University Press of Colorado. p 219-59.

Surovell TA, Waguespack NM, Mayer JH, Kornfeld M, Frison GC. 2005. Shallow site archaeology: artifact dispersal, stratigraphy, and radiocarbon dating at Barger Gulch Locality B Folsom Site, Middle Park, Colorado. Geoarchaeology 20(6):627-49.

Tamm CO, Östlund HG. 1960. Radiocarbon dating of soil humus. Nature 185(4714):706-7.

Trumbore SE. 2000. Radiocarbon geochronology. In: Noller JS, Sowers JM, Lettis WR, editors. Quaternary Geochronology: Methods and Applications. Washington, DC: American Geophysical Union. p 41-59.

Trumbore SE, Zheng S. 1996. Comparison of fractionation methods for soil organic matter ${ }^{14} \mathrm{C}$ analysis. $\mathrm{Ra}$ diocarbon 38(2):219-29.

Vierling LA. 1998. Palynological evidence for late- and postglacial environmental change in central Colorado. Quaternary Research 49(2):222-32.

Wang H, Hackley KC, Panno SV, Coleman DD, Chao-li Liu J, Brown J. 2003. Pyrolysis-combustion ${ }^{14} \mathrm{C}$ dating of soil organic matter. Quaternary Research 60(3): 348-55.

Wang Y, Amundson R, Trumbore S. 1996. Radiocarbon dating of soil organic matter. Quaternary Research 45(3):282-8.

Western Regional Climate Center. 2008. http:// www.wrcc.dri.edu. Accessed 20 January 2008. 